Cahiers $d u$ MONDE RUSSE

\section{Cahiers du monde russe}

Russie - Empire russe - Union soviétique et États indépendants

$58 / 1-2 \mid 2017$

1917

\title{
War, Refugeedom, Revolution
}

Understanding Russia's refugee crisis, 1914-1918

La guerre, les réfugiés, la révolution ou comment comprendre la crise des réfugiés en Russie, 1914-1918

\section{Peter Gatrell}

\section{OpenEdition}

\section{Journals}

Electronic version

URL: http://journals.openedition.org/monderusse/10073

DOI: $10.4000 /$ monderusse. 10073

ISSN: $1777-5388$

Publisher

Éditions de l'EHESS

Printed version

Date of publication: 1 January 2017

Number of pages: 123-146

ISBN: 978-2-7132-2696-0

ISSN: $1252-6576$

\section{Electronic reference}

Peter Gatrell, «War, Refugeedom, Revolution », Cahiers du monde russe [Online], 58/1-2 | 2017, Online since 01 January 2019, Connection on 02 January 2020. URL : http://journals.openedition.org/ monderusse/10073 ; DOI : 10.4000/monderusse.10073 


\section{WAR, REFUGEEDOM, REVOLUTION}

\section{Understanding Russia's refugee crisis, 1914-1918}

Human mobility has long preoccupied historians of Russia. Studies abound on the scale, dynamics and significance of internal migration in tsarist, Soviet and postSoviet Russia. Forced migration in the Stalin era has been a markedly fruitful field, but the richness of work on other periods should not be discounted. State practices and migrants' experiences have been the subject of significant recent interventions pointing to the role played by mobility in Russia in relation to broader historical processes. Lewis Siegelbaum and Leslie Page Moch focus as much on what they call "repertoires of migration" as they do upon institutional arrangements. In another important contribution, John Randolph and Eugene Avrutin suggest that “what happens 'on the move' can help us appreciate the intersection of many political, social, and cultural forces within the past and analyse their interplay without asserting the absolute supremacy of one over the other."1

These myriad forces were certainly evident during the First World War. When war broke out in 1914 it was widely understood that Russia had but recently recovered from the explosive events of war and revolution in 1904-1905. But mass population displacement, the phenomenon that tsarist contemporaries characterised as bezhenstvo [refugeedom], had no precedent in Russia's history. Refugeedom cast migration in an entirely new light. The tsarist state struggled to come to terms with

1. John Randolph and Eugene Avrutin, eds, Russia in Motion: Cultures of Human Mobility since 1850 (Champaign-Urbana: University of Illinois Press, 2012), quotation at p. 6; Lewis H. Siegelbaum and Leslie Page Moch, Broad is My Native Land: Repertoires and Regimes of Migration in Russia's Twentieth Century (Ithaca: Cornell University Press, 2014). Among many other studies, see Nicholas Breyfogle, Abby Schrader and Willard Sunderland, eds, Peopling the Russian Periphery: Borderland Colonization in Eurasian History (London: Routledge, 2007); Mark Bassin, Christopher Ely, and Melissa K. Stockdale, eds, Space, Place, and Power in Modern Russia: Essays in the New Spatial History (DeKalb: Northern Illinois University Press, 2010); Pavel Polian, Against Their Will: the History and Geography of Forced Migrations in the USSR (Budapest: Central European University Press, 2004, translated from the Russian edition, published in 2001). 
the unplanned migration of at least six million internally displaced people. In an attempt to put this in context, an eminent Russian demographer wrote subsequently that "in two short years the movement of refugees and evacuees was as considerable as it had been during the migration to Siberia over a 25-year period, 1885-1909."” Existing controls on population settlement could simply not be maintained. The emergency caught Russia unawares, obliging the tsarist government to invent policy on the hoof, not only to assist refugees but also to respond to the demand of educated society (tsenzovoe obshchestvo) for action. Nor did Russia's withdrawal from the war following the Bolshevik Revolution bring an end to the turbulent process of mass population displacement: the prolonged Civil War and related conflicts unleashed further demographic upheaval. A mass exodus of Bolshevik opponents from Russian territory was one manifestation of this upheaval. So, too, was the repatriation of millions of people who had been displaced during the war and who opted to return to homes that were now located in sovereign states, Poland, Lithuania, and Latvia. ${ }^{3}$

The protracted refugee crisis poses a challenge to the historiography of migration in Russia: how do historians accommodate refugeedom into existing interpretations of war and revolution? A flurry of recent scholarship has shed new light on the dimensions of displacement and the institutional changes that were introduced in wartime Russia to manage migration and assist refugees. But there remain other issues where historians have an opportunity to intervene. These include the relationship between governance and accountability, key issues today in refugee studies and in humanitarianism. Historians also need to establish more clearly the range of social attitudes towards refugees and the experiences of refugees themselves. ${ }^{4}$

This article examines the refugee crisis in Russia in the era of war and revolution, including questions about the source material, the historiography and the reasons for historiographical neglect; and about its political, social and cultural significance then and now, in the light of the refugee studies literature that has blossomed over the past quarter of a century. The political significance of the refugee crisis entails fundamental questions about the legitimacy of various forms of intervention designed to ameliorate the difficult situation faced by refugees. Focusing on "significance" directs our attention to issues around relief programmes, or what in current parlance would be characterised as humanitarian assistance. How did contemporaries understand the objectives of relief work? Should we characterise refugee relief efforts as the manifestation of humanitarianism, or were other impulses at play in Russia at this juncture? Repatriation also deserves scrutiny: this was as complex to undertake in post-1917 post-imperial Russian space as it has

2. Eugene M. Kulischer, Europe on the Move: War and Population Changes 1917-1947 (New York: Columbia University Press, 1948), 32.

3. Peter Gatrell, A Whole Empire Walking: Refugees in Russia during World War 1 (Bloomington: Indiana University Press, 1999).

4. These are huge topics. I have attempted to map the field in Peter Gatrell, The Making of the Modern Refugee (Oxford: Oxford University Press, 2013). 
proved to be in other contexts. ${ }^{5}$ The article also asks to what extent refugees were able to express themselves, whether to lament the circumstances leading to their displacement, to criticise the arrangements made on their behalf, or to articulate a sense of their future. Given the impressive volume of work that has used workers' testimony to illuminate Russian labour history, it is worth considering what kind of testimony survives from refugees.

The first two sections discuss some of the extant source material, including Anglophone accounts. The article goes on to consider the politics and practice of relief work. The penultimate section looks at the ramifications of population displacement in 1917 and beyond. The final section addresses directly the issue of refugee voices.

\section{Historiography and sources}

Two very broad and related factors explain the transformation of the field of study in the last 20 years or so. The first is the collapse of communism and the grand challenge to a Soviet orthodoxy that neglected social groups that could not be accommodated in a Marxist-Leninist framework. After 1991 it became possible to consider the destabilising impact of war beyond the revolutionary working class and armed forces. ${ }^{6}$ The second factor is what might broadly be termed a post-modern subversion of grand historical narratives, which took place at around the same time that public opinion in the West gained a greater awareness of the magnitude of fresh population displacement across the globe, including in Afghanistan, Yugoslavia and Rwanda. It is also important to add that post-Soviet historians were living in a radically different spatial as well as political environment; they could not fail to be aware of the shock of territorial reconfiguration and its impact on population displacement in the former Soviet Union. ${ }^{7}$ For these reasons, there has lately been an efflorescence of work by scholars on wartime population displacement in Russia and Ukraine, and also in Belarus, the Baltic countries, and

5. An excellent guide to refugee studies is Elena Fiddian-Qasmiyeh, Gil Loescher, Katy Long and Nando Sigona, eds, The Oxford Handbook of Refugee and Forced Migration Studies (Oxford: Oxford University Press, 2014).

6. In addition to work cited below, see A.N. Kurtsev, "Bezhentsy pervoi mirovoi voiny [Refugees of the First World War]," Voprosy istorii, no. 8 (1999): 98-113; Eric Lohr, Nationalizing the Russian Empire: The Campaign against Enemy Aliens during World War 1 (Cambridge, MA: Harvard University Press, 2003), Joshua Sanborn, "Unsettling the Empire: Violent Migrations and Social Disaster in Russia during World War I," Journal of Modern History, 77, 2 (2005): 290-324; Willard Sunderland, The Baron's Cloak: A History of the Russian Empire in War and Revolution (Ithaca: Cornell University Press, 2014).

7. Rogers Brubaker, "Aftermaths of Empire and the Unmixing of Peoples," in Karen Barkey and Mark von Hagen, eds, After Empire: Multiethnic Societies and Nation-Building: The Soviet Union and the Russian, Ottoman and Habsburg Empires (Boulder: Westview Press, 1997), 155-80; Peter Gatrell, "World Wars and Population Displacement in Europe in the Twentieth Century," Contemporary European History, 16, 4 (2007): 415-426. 
Poland. These publications bring fresh archival material to light on charitable relief and the organisation of social welfare, particularly at a local and regional level. ${ }^{8}$

Yet for decades the only publication of note in Russian relating to population displacement in the era of the First World War was a brief and tantalising encyclopedia entry on "refugeedom" by Abram Kirzhnits in the first edition of the Soviet historical encyclopedia. Kirzhnits was at pains to emphasise that civilians quit their homes in Russia's western borderlands on account of enemy invasion in the first phase of the war, but that mass population displacement also resulted from the concerted actions of the tsarist army in deporting civilians from Grodno, Kovno, Kurland and other provinces. Kirzhnits termed this a "bacchanalia of forced migration" (bakkhanaliia vysleneniia) that ensnared Poles, Jews, Latvians, Lithuanians, Belarusians and Ukrainians. These minorities were targeted on account of their presumed disloyalty to the empire; Jews in particular suffered from widespread antisemitism. One of the consequences of their deportation - the dissolution of the Pale of Settlement - was unexpected, although according to Kirzhnits the presence of Jews in the Russian interior did little to lessen the prejudice they faced. ${ }^{9}$ Kirzhnits relied upon official and semi-official accounts to paint a picture of the scale of the refugee crisis and the most notable organisations involved in relief work, including the assistance provided by trade unions in Moscow, Riga, Samara, and elsewhere. The sources remained buried in the archives of pre-revolutionary government and non-governmental institutions. But these institutions evaporated-or were eviscerated - and this helped foster historical amnesia about refugeedom.

Little work of note on the refugee crisis therefore appeared in the Soviet era. One exception proves the rule: the memoirs of Evgenii A. Nikol'skii were written in exile and subsequently deposited in the Hoover Institution. His memoirs include around one hundred pages on "Refugees during the Great War."10 Nikol'skii had first-hand experience of assisting refugees as they travelled in summer 1915 from

8. Gatrell, A Whole Empire Walking; Nick P. Baron and Peter Gatrell, eds, Homelands: War, Population and Statehood in the Former Russian Empire, 1918-1924 (London: Anthem Books, 2004); Mariusz Korzeniowski, Marek Mądzik and Dariusz Tarasiuk, Tułaczy los Uchodźcy polscy $w$ imperium rosyjskim $w$ latach pierwszej wojny światowej [Wandering fate: Polish refugees in the Russian Empire during the First World War] (Lublin: Wydawnictwo Uniwersytetu M. Curie-Sklodowskiej, 2007); Tomas Balkelis and Violeta Davoliūte, eds, Population Displacement in Lithuania in the 20 century: Experiences, Identities and Legacies (Amsterdam: Brill-Rodopi, 2016), particularly the essays by Balkelis, Andrea Griffante, and Klaus Richter; Peter Gatrell and Liubov Zhvanko, eds, Europe on the Move: the First World War and its Refugees (Manchester: Manchester University Press, 2017).

9. A. Kirzhnits, "Bezhenstvo [Refugeedom]," Sovetskaia istoricheskaia entsiklopediia, vol. 5 (M., 1927), cols. 176-177. Kirzhnits (1888-1940) was a journalist, historian and bibliographer. Born in Bobruisk (Babryusk), he attended school in Belostok before being expelled for revolutionary activity. In 1915, partly on account of his activities on behalf of the Bund, he was deported to Siberia where he worked for several Siberian newspapers. In 1920 he returned to Belarus where he resumed his career as a journalist before taking up a post in Moscow as editor of Moskovskii proletarii. His main interests were the Jewish labour movement and the history of the Jewish press. He was arrested in 1937.

10. E.A. Nikol'skii, "Bezhentsy v velikuiu voiny 1914-1918 gg. [Refugees in the Great War 1914-1918]," included in his "Zapiski o proshlom za 55 let [Notes on the past 55 years ]" (unpublished manuscript, San Francisco, 1934). 
the vicinity of Kobrin/Kobryn in Russian Poland, around $25 \mathrm{~km}$ from the front line, where many thousands had been kept in temporary refugee camps, to the Russian interior. Shortly afterwards he was engaged by Severopomoshch' (literally, "Northern Aid"), part of the bureaucratic apparatus created by the Ministry of the Interior as a rival to the public organisations that were operating in the vicinity of the front (see below). ${ }^{11}$

Nikol'skii began his account by acknowledging the paucity of scholarship on the refugee crisis, and of course, his decision to emigrate after the Bolshevik Revolution gave him a particular perspective on the disastrous consequences of the First World War. He provided a vivid description of the plight of refugees and their arduous journey to European Russia via the Pinsk marshes once it became clear that they were unlikely to be able to return to their homes any time soon. Most refugees had been forced to abandon their livestock, since no room could be found for draft animals on the trains from Roslavl' to Moscow. He drew an important distinction between refugees of modest means and those from a more privileged background. Another key point was the fact that the decisions taken by the Russian army had direct repercussions on refugees, but that military commanders evinced no interest in the relief of refugees. Nikol'skii also maintained that Severopomoshch' and other aid organisations employed an excessive number of staff who thereby evaded the military draft including, as he put it, "many Jews."12

In emphasising that "no-one who was not present to witness these events can have any idea of the suffering that these unfortunate people had to endure," Nikol'skii spoke in terms that are common to other accounts of refugee crises. He admitted that he had neither "the paints, nor the talent" to describe the terrible experiences of refugees, which included not only the risk of contracting cholera or typhus but also intermittent exposure to aerial bombardment. He added - another familiar flourish - that refugees had become a "chaotic throng" liable to panic at the first sign of the enemy. In more sympathetic vein he stressed refugees' attempts to re-establish contact with loved ones from whom they had become separated. But he also bemoaned the fact that refugees took matters into their own hands, particularly when it came to seeking out stocks of food. This - the purchase of food and its distribution at specified points to bona fide refugees - he regarded as his responsibility. ${ }^{13}$

In sum, Nikol'skii betrayed a degree of prejudice along with his acute realisation of the magnitude of the refugee crisis. Like other contemporaries he voiced anxiety about the behaviour of refugees whose "spontaneous" actions threatened to make an already intolerable situation in the Russian interior even worse. As we shall see, this sense of impending catastrophe takes the reader into the realm of political crisis and notions of social collapse.

11. Gatrell, A Whole Empire Walking, 43; Nikol'skii, “Zapiski,” 240.

12. Nikol'skii, “Zapiski,” 215, 241-242.

13. Ibid., 257-258, 262-266. 


\section{Distant suffering: contemporary Anglophone views of the refugee crisis}

The plight of refugees in the Russian Empire first came to the attention of the English-speaking world in 1915 when the Englishman John Pollock published an article in the Fortnightly Review. Pollock (1878-1963) belonged by virtue of his privileged background to the British elite. During the First World War he served as chief commissioner of the Great Britain-Poland Fund (originally the "Great Britain to Poland and Galicia Committee"). ${ }^{14}$ In July 1915 he travelled to Kiev under the auspices of the Russian Red Cross. His article described "a pool of human misery [...] a world apart from anything known before [...] its inhabitants are of one class, one type, one character, and they have but one name. They are the Refugees." He added that this "wailing multitude [has] reached the point of complete apathy." Most of them were Ruthenian peasants from Galicia who "in everything tend towards Russian culture" (sic). Pollock evoked the idea of the early medieval "'wandering of the peoples" as the only equivalent to this mass movement of population. Deploying another cultural reference, he described a baby at its mother's breast; the woman had "a face like Michelangelo's Delphic Sybil on the Sistine Chapel." The only crumb of comfort was the delivery of hot meals and baths by a British committee headed by a Yorkshire engineer who had narrowly "escaped from death on the Galician oilfields." There was also a promise of help from the Tatiana Committee (see below) ${ }^{15}$ In general, Pollock's account was characterised by a patronising tone, reinforcing a sense that refugees might be helped, but could not help themselves. This, and his repertoire of cultural allusions, makes it worthy of note.

A more extensive and informative account of refugees in Russia appeared in 1916, penned by British nurse Violetta Thurstan (1879-1978). Thurstan joined the British Red Cross in 1913 and spent several weeks helping the war wounded in Belgium until she transferred to the Russian Red Cross. She wrote of her experiences in two books including a unique account in English, The People Who Run: the Tragedy of the Refugees in Russia. After leaving Russia she returned to Belgium, where she was wounded, before taking up a position as a hospital nurse in Macedonia where she remained until the end of the war. After the war she turned her attention to other pursuits, but she did not abandon her interest in refugees. In 1923 she took a post with the Egyptian government as director of Bedouin industries in

14. "Polish relief," The Times (London), 2 April 1915, noted that "every pound will save 32 people from starvation for a week." An obituary in The Times, 23 July 1963, explains that he was educated at Eton and Trinity College, Cambridge, before becoming a newspaper correspondent in Helsinki, Berlin and Paris. Pollock's book, War and Revolution in Russia: Sketches and Studies (1918), reprints some of his journalism and includes an account of his escape from Bolshevik captivity.

15. John Pollock, "The Refugees at Kiev," Fortnightly Review, 585 (September 1915), 476-479. Violetta Thurstan was full of praise for the work of the Tatiana Committee in Kiev, which compared very favourably to the situation in other cities. Another observer of the refugee crisis was the American archaeologist Thomas Whittemore, but he left no published account of his work. Gatrell, A Whole Empire Walking, 81. 
Arab refugee camps close to Cairo where women were employed in carpet making. In 1937 she worked in Spain helping wounded civilians during the civil war and working on behalf of prisoners. At the end of the Second World War her career in refugee relief continued when she joined the Catholic Relief Programme, evacuating and resettling children, working with prisoners of war and displaced persons in Italy, Egypt, and Austria. ${ }^{16}$ She belongs to that large body of British female voluntary aid workers who moved from country to country in the middle years of the $20^{\text {th }}$ century, gaining expertise in the field as they did so. ${ }^{17}$

The People Who Run drew on Thurstan's experiences of the initial Russian retreat to Warsaw and the great retreat in summer 1915 during which she worked in a series of field hospitals. ${ }^{18}$ Like Pollock, she revealed a sensitive if somewhat patronising approach to refugees - "some of the saddest people that ever were seen" - whose overcrowded accommodation meant "the indiscriminate mingling of the decent and the dissolute." She frequently came into contact with apathetic refugees, but she drew a distinction between lethargy and "slacking and shamming," since inertia could not be helped. Refugees had, in her view, lost a sense of self-respect, but they deserved sympathy: "their sorrow [...] is a vicarious one, for they have suffered and died in order that our homes, our country and our children shall be safe." She distinguished between men and women:

The old men can be made content with a little tobacco and the company of their old cronies; perhaps, too, they are a little more used to travelling and mixing with the outside world than the women, who seem to miss terribly their accustomed seat near the stove among their familiar household goods. ${ }^{19}$

Warming to her theme about population displacement and the consequences attendant on the collapse of patriarchal authority, including what she saw as a loss of moral compass, Thurstan praised female students in Petrograd who "have done admirable work in keeping the young girls straight and out of temptation" and singled out aid organisations that arranged classes for young boys "on the Boy Scout principles" who were taught a trade and thereby encouraged to keep out of mischief. ${ }^{20}$

16. Melissa Hardie-Budden, "Thurstan, Anna Violet (1879-1978)," Oxford Dictionary of National Biography, Oxford University Press, October 2008 [http://www.oxforddnb.com/ view/article/59611, accessed 12 January 2016].

17. Sibyl Oldfield, Doers of the World: British Women Humanitarians 1900-1950 (London: Continuum, 2006).

18. Her other works include Field Hospital and Flying Column (New York: G.P. Putnam's Sons, 1915). See also Christine Hallett, Veiled Warriors: Allied Nurses of the First World War (Oxford: Oxford University Press, 2014); Laurie S. Stoff, Russia's Sisters of Mercy and the Great War: More Than Binding Men's Wounds (Lawrence: University Press of Kansas, 2015).

19. Violetta Thurstan, The People Who Run: The Tragedy of the Refugees in Russia (New York: G.P. Putnam's Sons, 1916), 38.

20. Thurstan, The People Who Run, 72. 
Thurstan was also attentive to the impact of the war on ordinary Russians who were confronted by a massive sudden influx of refugees. Poor households in particular faced mounting household bills as the price of food and rents rose. She noted the desperate situation in some provincial cities, such as Kazan, where refugees and locals were also expected to share resources with Austrian prisoners of war and wounded soldiers who were being treated in the university medical school. In these circumstances, she could only express admiration for peasants who treated refugees "as members of the family." 21 However, her compassion did not extend to Jews in general or to Jewish refugees in particular. Thurstan betrayed her own prejudices when announcing that "many Jews have on the whole German sympathies." Nor did Jewish refugees "suffer so acutely from homesickness [since] they are wanderer by nature or sub-conscious instinct. They settle down more quickly [...] and take more easily to new work." Another consideration in her view was that their situation was mitigated by "the extraordinary generosity shown by many Jews to their co-religionists," by which she meant the financial aid from Jews living overseas. ${ }^{22}$ In her view, other refugee groups deserved greater sympathy and attention.

The accounts published by Thurstan and Pollock lend weight to the suggestion that the Russian refugee crisis generated a powerful sense of what has come to be called 'distant suffering' that relied upon graphic representations of distress and allusions to culturally familiar episodes from the past. ${ }^{23}$ Pollock and Thurstan both appealed for donations from members of the British public. Thurstan in particular drew attention to international interest in Russian refugees from the National Union of Women's Suffrage Societies, the Salvation Army, and the Great Britain-Poland Fund, which placed an advert in her book to inform readers of the use to which their donations would be put. To be sure, her emphasis on Allied charity was calculated to sustain the commitment of the British public to its Russian ally, but taking a broader view we can also see the articulation of a business-like humanitarian ethos in which considerations of value for money mattered no less than the relief of suffering. ${ }^{24}$

\section{Contours of crisis and relief efforts}

For a number of reasons the Russian press devoted considerable attention to the plight of refugees during the war. Russian newspapers and periodicals reported on

21. Ibid., 142-143.

22. Ibid., 150-153. See also The Jews in the Eastern War Zone (New York: The American Jewish Committee, 1916).

23. Luc Boltanski, Distant Suffering: Morality, Media, and Politics (Cambridge: Cambridge University Press, 1999).

24. Thurstan's point about the destination, purchasing power and effectiveness of the British pound, speaks to recent work on the accountability of charitable enterprise. Sarah Roddy, Julie-Marie Strange and Bertrand Taithe, "The Charity-Mongers of Modern Babylon: Bureaucracy, Scandal, and the Transformation of the Philanthropic Marketplace, c.1870-1912," Journal of British Studies, 54, 1 (2015): 118-137. 
the relief efforts undertaken by the government, by semi-official bodies such as the Tatiana Committee for the Relief of War Victims, by public organisations, notably the Union of Zemstvos and the Union of Towns, and by diocesan committees and private individuals, as well as by newly-formed national committees, all of which exercised significant leverage and enjoyed considerable leeway. ${ }^{25}$ There were several reasons for the attention given to the refugee crisis in Russian public life. Chief amongst them were the suddenness and scale of population displacement in the spring and summer of 1915. But the crisis also afforded an opportunity for different political interests to capitalise on the crisis, and to project fears of social and economic instability on to refugees. Rival groups vied in asserting their readiness to alleviate civilian suffering and to establish their claims to do so in a timely and competent fashion. In short, mass population displacement was politicised as a crisis of refugeedom.

In the first instance, of course, refugees served as an emblem of enemy brutality. Russian propaganda concentrated on the perpetration of atrocity by German and Austrian troops, much as the Allies denounced Germany's invasion and occupation of Belgium. "The enemy [reported a senior Russian official] destroys everything, leaving nothing intact. Villages are razed to the ground, homes are burned down; where before there was calm and prosperity, now there is devastation, and the population has lost all that is precious." ${ }^{26}$ On the Caucasus front, too, Armenian observers in cities such as Yerevan referred to "the barbaric actions of Turks and Kurds." In a speech given in March 1915, the renowned parliamentarian Paul Miliukov stated that "each time Russia goes to war with Turkey, the Armenian subjects of the Ottoman Empire suffer [...] including suffering for their belief that at some stage Ararat will be free [from Turkish rule]. Let Russian society show the same measure of sympathy as it has shown for the freedom of Belgium, Serbia and Poland." 27 In other words, the heavy responsibility for refugees' suffering lay squarely on the shoulders of Russia's adversaries.

What was left out of account in this framing of crisis were the concerted attempts by the Russian high command to organise the eviction and resettlement of Jews, Poles, Latvians and others, including the German subjects of the Tsar. Russian generals confidently asserted that "the complete hostility of the entire Jewish population towards the Russian army is well established." Russian troops, including Cossack soldiers far from home who encountered Polish Jews for the first time,

25. For early accounts by contemporary participants, see P. Gronsky and N.I. Astrov, The War and the Russian Government (New Haven: Yale University Press, 1929), and Tikhon Polner, Russian Local Government during the War and the Union of Zemstvos (New Haven: Yale University Press, 1930).

26. Remarks of A.B. Neidgardt, reported in Komitet ee Imperatorskogo Vysochestva Velikoi Kniazhny Tatiany Nikolaevny po okazaniiu vremennoi pomoshchi postradavshim ot voennykh deistvii, 14 sentabria $1914 \mathrm{~g}$. po ianvaria $1916 \mathrm{~g}$.) [The Committee of Her Royal Highness Tatiana Nikolaevna for the temporary relief of victims of war, 14 September 1914 to January 1916], volume 1 (Petrograd, 1916), 244.

27. Mshak, 76 (1 April 1915). Miliukov is quoted in Mshak, 60 (22 March 1915). 
easily mistook Yiddish for German, and this ignorance only reinforced the message from their superiors that Jews were not to be trusted. Such distorted preconceptions underpinned widespread attacks on Jews and Jewish property. What began as sporadic and unsystematic actions in 1914 turned into methodical deportations in the spring of 1915, accompanied by mass looting. As many as 600,000 Russian Jews were displaced..$^{28}$ The Russian high command and the Ministry of the Interior also drew up plans as early as August 1914 for the removal of German settlers from several districts in the western borderlands. One leading government official expressed a widely-held view: "the colonists [...] live so detached an existence from the native Russian population that, all in all, they constitute a ready base for a German attack through our southern provinces." By the end of the year, after a vitriolic press campaign, steps were taken to drive them all out of the western borderlands. Around 200,000 individuals were affected by this action, their journeys to Siberia supervised by armed military or police detachments. ${ }^{29}$

Only fragments of this story emerged during the war. One clue to the actions of the state in unleashing mass displacement was the decree of 30 August 1915, according to which refugees were defined as "individuals who left their localities under the threat of or occupied by the enemy" but also who were "deported from the military zones at the command of either military or civil authorities." The decree also encompassed "individuals originating from Russia's enemy states." 30 The categories and procedures for determining refugees' eligibility are hotly debated in refugee studies, but in wartime Russia the distinction between those who "fled" and those who were forcibly removed deported became blurred. Instead, contemporary discourse referred to "victims of war" or to "refugees" without distinguishing between the causes of displacement. ${ }^{31}$

Government oversight of the refugee question rested with the new Special Council for Refugees [Osoboe soveshchanie po ustroistvo bezhentsev], which was established in August 1915. Like other special councils created in the same month, it was chaired by a cabinet minister, in this case the minster of the interior. It allocated around 200 million rubles in the course of the war, equivalent to more than two-thirds of total expenditure on refugee relief..$^{32}$ The special council was not

28. Eric Lohr, Nationalizing the Russian Empire: the Campaign against Enemy Aliens during World War I (Cambridge, MA: Harvard University Press, 2003); Joshua A. Sanborn, Drafting the Russian Nation: Military Conscription, Total War and Mass Politics, 1905-1925 (DeKalb: University of Northern Illinois Press, 2003), 116-22. For a contemporary account, see Polly Zavadivker, ed., 1915 Diary of S. An-sky: A Russian Jewish Writer at the Eastern Front (Bloomington: Indiana University Press, 2016).

29. Gatrell, A Whole Empire Walking, 23-24.

30. Zakony i raspolozheniia o bezhentsakh [Laws and arrangements about refugees] (M., 1916), 2; Osobye soveshchaniia i komitety voennogo vremeni [Special commissions and councils in wartime] (Petrograd, 1917), 47.

31. Gatrell, A Whole Empire Walking, 33-48; Andrew Shacknove, "Who is a Refugee?" Ethics, 95, 2 (1985): 274-284; Roger Zetter, "More Labels, Fewer Refugees: Remaking the Refugee Label in an Era of Globalisation," Journal of Refugee Studies, 20, 2 (2007): 172-192.

32. Kirzhnits, "Bezhenstvo." 
immune from the effects of the growing economic crisis, and in December 1916 informed the organisations it funded of the need to adjust to a 50 per cent cut in their budget. At the same time, the Tsar's plenipotentiary in the Caucasus instructed relief agencies to enlist refugees in the search for paid work, in order to reduce their reliance on government funds..$^{33}$ The question of entitlement emerged in discussions of the arrangements for the registration of refugees at a local level. In Khar'kov, for example, refugees who approached the municipality for assistance had to "demonstrate that they are actually from areas suffering from military action." 34

The Tatiana Committee (Komitet Ee Imperatorskogo Vysochestva Velikoi Kniazhny Tatiany Nikolaevny dlia okazaniia pomoshchi postradavshim ot voennykh deistvii) occupied pride of place in the operational arrangements for refugee relief. It collected and distributed cash and goods to all refugees. It published lists and photos of refugee children who had been separated from their parents. Although critics accused it of being an establishment entity, this was much less true of the committee's regional branches which, as in Novgorod, included priests, landlords, teachers, lawyers, workers and peasant farmers. It galvanised middle-class women into collecting money, distributing food and warm clothing, arranging temporary accommodation for refugees and finding them part-time work in order to maintain their morale. ${ }^{35}$ The committee supplemented its budget from the central government with private donations and from funds derived from organised campaigns such as those associated with the Tsar's daughter's name-day. Its employees drew no salary, so overheads were low, as its chairman, senator Aleksei B. Neidgardt reminded the Russian public, in a barb directed at the rival public organisations. ${ }^{36}$

Early in the war Tsar Nicholas II also approved the formation of the union of zemstvos and the union of towns. Their leaders envisaged closer collaboration between themselves, and in July 1915 they revived the joint organisation, Zemgor, which had briefly seen the light of day during the Russo-Japanese War. In addition to attempting to improve military supplies, Zemgor took steps to support refugees, particularly during the long and arduous journey from the western borderlands to the Russian interior. These self-styled public organisations (obshchestvennye organizatsii) maintained not only that the wheels of officialdom turned slowly and that civic activism outstripped anything that could be expected from organisations associated with the state, notably the Red Cross and the Tatiana Committee. Like

33. Letter dated 15 December 1916, Tsentral'nyi gosudarstvennyi arkhiv Armenii [Central State Archive of Armenia], f. 50, op. 1, d. 127, 1.90.

34. Komitet ee Imperatorskogo Vysochestva, 453.

35. Ibid., 258-260, 416-417 (reports from Novgorod and Tver' respectively).

36. See the report by Neidgardt to the congress of activists of the Tatiana Committee meeting between 16 and 19 April 1917, Izvestiia Vserossiiskogo komiteta dliia okazaniia pomoshchi postradaiushchikh ot voennykh bedstvii [News of the All-Russian Committee for aid to victims of war], 20 (1917). Neidgardt, a conservative landowners from Nizhnii Novgorod, was P.A. Stolypin's brother-in-law. In 1918 he and his family were shot by the Bolsheviks. On the public organisations, see Olga Pichon-Bobrinskoy, "Action publique, action humanitaire pendant le premier conflit mondial: les zemstvos et les municipalités," Cahiers du Monde russe, 46, 4 (2005): 699-718. 
the Tatiana Committee, the public organisations maintained an active profile at a provincial level. ${ }^{37}$

Alongside these bodies, new national committees assumed considerable importance during the war to assist non-Russian refugees, particularly Latvian, Lithuanian, Armenian, Polish, and Jewish refugees - significantly, no special provision was made for Ukrainian refugees ${ }^{38}$ In one sense the emergence of national committees is unsurprising given the geographical contours of war in the multinational Russian Empire. But the licence they received was unprecedented. This freedom of action owed much to the resource constraints of the tsarist state, which was obliged to devolve much of the day-to-day responsibility for refugee relief on to these committees, whose leaders were given seats on the Special Council and on the Tatiana Committee. Patriotic activists seized the opportunity to express a sense of "national" calamity that in turn required solidarity. Deliberate action was needed, in the words of the Latvian activist Janis Goldmanis, to ensure that Latvians avoid "the lot of the Jews, to be scattered across the entire globe." Polish activists spoke of "preserving the refugee on behalf of the motherland." Lithuanian clergy paid close attention to the moral fibre of refugees.$^{39}$ Generally speaking, displacement afforded these patriotic elites direct access to a nascent national community. Refugee relief instructed the displaced farmer or labourer what it meant to be Armenian, Polish, Jewish or Latvian. Wartime encounters between different ethnic groups-one thinks of instances when Latvians or Poles were mistaken for Germans and targeted accordingly - reinforced a sense of ethnic particularism. Goldmanis was not alone in articulating a vision of a reclaimed homeland, whose farms should in due course be re-populated by "people who think and act in a Latvian manner." 40

National committees challenged existing non-Russian communities to come to the aid of those with a similar ethnic background - for example, by organising a head-count of refugees and levying taxes on settled co-nationals in provincial towns and cities in European Russia, thereby forcing them to confront the question of their "identity." Already at the beginning of 1915, for example, the Tbilisi-based newspaper Mshak [Labourer] reported that 100,000 Armenian refugees (as well as Assyrians and Greeks) had crossed into Russia from Turkey and Persia. It called upon Armenian "colonies" in Petrograd, Moscow, Odessa, Ekaterinodar and other cities to focus on what it termed "a national question." Russian Armenians donated money to support refugees who already thronged Yerevan and Etchmiadzin. In the spirit of accountability, the committees also explained to readers how their donations were being spent and justified their existence with reference to the

37. Gatrell, A Whole Empire Walking, 37-47.

38. National relief committees also operated in German-occupied Lithuania on behalf of Lithuanian, Polish and Jewish groups. See Andrea Griffante, "Making the Nation: Refugees, Indigent People, and Lithuanian Relief, 1914-1920," in Balkelis and Davoliūtè, eds, Population Displacement in Lithuania, 21-41.

39. Tomas Balkelis, "Forging a 'Moral Community': the Great War and Lithuanian refugees in Russia," in Balkelis and Davoliūte, eds, Population Displacement in Lithuania, 42-61.

40. See the sources quoted in Gatrell, A Whole Empire Walking, 156, 159. 
effectiveness of the aid they delivered. Newspapers published accounts that itemised in detail the number of meals and beds that had been assigned to refugees. ${ }^{41} \mathrm{~A}$ similar response applied to other minorities. At a local level the different national committees got on reasonably well and encouraged local communities to set aside any differences on "fraternal" grounds. They mobilised refugees by linking relief to ethnicity, with impressive results that ultimately contributed to the destabilisation of the Russian Empire. ${ }^{42}$

The significance of the relief effort was not confined to political ambitions. Fears-anxieties around social upheaval, moral collapse, health crises-were projected on to refugees. Ten years after the revolution, Kirzhnits alluded to the fact that refugees yielded to "spontaneous" impulses in order to save their skin or were despatched to the Russian interior by tsarist military commanders in a haphazard fashion. ${ }^{43}$ But this was already a common trope, serving both to highlight refugees' loss of self-control and to legitimise an extensive intervention by professional expertise-social workers, doctors, nurses, psychiatrists, lawyers, statisticians, teachers, and so on. This is not to underestimate the extent of suffering that afflicted hungry and sick refugees or to minimise the psychological consequences of separation from family members and the overwhelming uncertainty of war. But it draws attention to the ways in which displacement was being characterised at the time. Charitable relief work necessitated the creation of images of suffering that portrayed refugees as passive victims of war who needed guidance to recover their capacity to make a contribution to society. ${ }^{44}$

\section{Refugees, revolution and repatriation: 1917 and beyond}

The scale of population displacement in the Russian Empire during the war beggared belief. Russia's refugee crisis did not cease with the overthrow of tsarist rule. According to the renowned Soviet demographer, E.Z. Volkov, the total number of refugees in Russia on 1 January 1917 stood at just over six million. Six months later, as the war showed no signs of coming to an end, it had increased to 7.4 million. At the beginning of 1918, following the Bolshevik Decree on Peace,

41. "O bezhentsakh [On refugees ]," Mshak, 2 (4 January 1915). In March 1915 some refugees opted to return to their villages in order to prepare for the spring sowing, under the protection of the Russian army, as reported in Mshak, 58 (18 March 1915).

42. Gatrell, A Whole Empire Walking, 168-70. Here, too, students of the wartime refugee crisis are indebted to findings in refugee studies that detect powerful expressions of "national identity," particularly where refugees from specific ethnic groups are closely confined. The classic statement is Liisa Malkki, Purity and Exile: Violence, Memory, and National Cosmology among Hutu Refugees in Tanzania (Chicago: Chicago University Press, 1995). For more on wartime mobilisation in Russia, see Melissa K. Stockdale, Mobilising the Russian Nation: Patriotism and Citizenship in the First World War (Cambridge: Cambridge University Press, 2016), particularly chapter 4, "War Relief and the Language of Citizenship."

43. Kirzhnits, "Bezhenstvo."

44. Gatrell, A Whole Empire Walking, 73-83. 
Russia's new leaders calculated that the number was around four million, but since this figure only took account of the territory under its control, the real figure was certainly much higher. ${ }^{45}$

Political changes inevitably affected the administration of refugee relief. Pressure mounted in 1917 for reform. On the eve of the February Revolution a progressive newspaper editor wrote that "the ruling classes and the spokesmen of countless government departments keep telling us that the care of refugees, like the war itself, is a national affair. Well, if this is the case, give the people themselves the chance to speak their mind." ${ }^{6}$ Unsurprisingly, the Tatiana Committee had a hard job countering the call for its democratisation. Its leadership took steps to address its elite character, dropping Tatiana's name, introducing elections to key posts in spring 1917, and inviting refugees themselves to stand for office - a radical departure, given that it has not been common practice to involve refugees in managing their own affairs. ${ }^{47}$ There followed a broadly-based congress devoted to refugees in April 1917 at which they were promised personal respect in return for espousing the doctrine of self-reliance, an acknowledgement not only of the new political atmosphere but also of the dwindling resources for refugee relief. Administrative changes did nothing to address the fundamental financial difficulties faced by aid agencies during the worsening economic crisis. ${ }^{48}$

Democratisation also influenced the stance taken by national committees. The political activism of the professional intelligentsia enabled them to claim a share in the leadership of the national movements that burgeoned after February 1917. The collapse of the old regime created a political space for Latvian, Lithuanian, Polish and other patriots to articulate a vision of freedom and greater autonomy. But it was heavily qualified, as is evident from the experience of Latvian activists who faced the dispersal of so many potential citizens: as one progressive newspaper put it, "the only people to have returned are men on the make, spivs and the kind of women who have a bad name [...] Latvia is beset by lethargy, military discipline, money and cheap favours. There is only one solution, and that is for the Latvian intelligentsia to go back home." Unfortunately, the late summer of 1917 brought further disaster. German troops entered Riga on 21 August, Russian forces retreated

45. E.Z. Volkov, Dinamika narodonaseleniia SSSR za voseḿdesiat let [Dynamics of the population of the USSR over 80 years ](M.: Gosudarstvennoe izdatel'stvo, 1930), 70-73; Gatrell, A Whole Empire Walking, 212-213.

46. V. Muizhel', cited in Gatrell, A Whole Empire Walking, 172.

47. Trudy Vtorogo Vserossiiskogo s"ezda predstavitelei mestnykh otdelenii Vserossiiskogo komiteta dliia okazaniia pomoshchi postradaiushchikh ot voiny (Tatiianskogo), 16-19 aprelia $1917 \mathrm{~g}$. [Proceedings of the Second All-Russian Congress of local branches of the All-Russian Committee for the Relief of Victims of War (Tatiana committee), 16-19 April 1917](Petrograd: Gosudarstvennaia tipografiia, 1917), 80-87. On the lack of refugee participation in relief work, see the critique by Barbara Harrell-Bond, "The Experience of Refugees as Recipients of Aid," in Alistair Ager, ed., Refugees: Perspectives on the Experience of Forced Migration (London: Continuum, 1999), 136-168.

48. Gatrell, A Whole Empire Walking, 176-178. 
in disarray, and the number of refugees swelled yet again. ${ }^{49}$ The resulting political uncertainty continued after the October Revolution, which drew yet greater attention to divisions between the Bolsheviks, other socialists, liberals and conservatives as to the stance to adopt towards refugees.

As the Russian war effort ground to a halt towards the end of 1917, large numbers of non-Russian refugees remained scattered throughout the old empire. Many of them made plans to return, others threw in their lot with the Bolsheviks, rejecting the national committees in favour of class-based organisations, notably the soviets. In the short term the prospect of peace encouraged the first steps enabling refugees to return to their homes. Some refugees managed to travel surreptitiously, but the administrative and logistical difficulties proved insurmountable for most. In any case, the Soviet authorities frowned upon "spontaneous" repatriation..$^{50}$

In the immediate weeks following Brest-Litovsk, the Soviet government entrusted the administration of re-evacuation to the national committees whose provincial officials actively sought to establish the size and current place of residence of the refugee population. However, much of their work was quickly taken over by a new Soviet authority. At the end of April 1918 the Soviet Central Administration for Prisoners of War and Refugees (Tsentroplenbezh) came into being, by which time, however, local and regional soviets had begun to claim a more prominent role in determining the future of refugees, with the aim of supplanting purely "national" bodies. Tsentroplenbezh launched a fresh registration of refugees on Soviet territory. ${ }^{51}$ In its first six months of operation, Tsentroplenbezh and its regional offices assisted 400,000 refugees to return to their homes, mostly in states that had recently declared their independence. National organisations continued to apply themselves to the task of refugee relief and to engage in cultural and educational projects to promote "national consciousness" among the "inert masses." By June 1918 Soviet regional authorities felt sufficiently confident to curtail the activities of all non-governmental organisations in the sphere of refugee relief..$^{52}$

49. Dzimtenes Atbalss, 5 April 1917; Dzimtenes Atbalss, 5 July 1917; Gatrell, A Whole Empire Walking, 179-187; Balkelis, "Forging a "moral community'," 52-53.

50. I.P. Shcherov, Tsentroplenbezh v Rossii: istoriia sozdaniia i deiatel'nosti v 1918-1922 gg. [Tsentroplenbezh in Russia: the history of its formation and activity in 1918-1922], (Smolensk: Smolenskaia gosudarstvennaia tipografiia, 2000); Liubov Zhvanko, Bizhentsi Pershoi svitovoi viiny: ukrains'kyi vymir, 1914-1918 rr. [Refugees of the First World War: the Ukrainian reality, 1914-1918](Khar'kiv: Apostrof, 2012). In February 1920 Tsentroplenbezh was renamed "Tsentroevak" and transferred from the commissariat of war to the NKVD.

51.Gatrell, A Whole Empire Walking, 188-90; I.P.Shcherov, "Zapadnyi plenbezh (1918-1920 gg.) [Western Plenbezh, 1918-1920]," Voprosy istorii, 9 (1998), 130-133; V.S. Utgof, "Reevakuatsiia belorusskikh bezhentsev pervoi mirovoi voiny, nachal'nyi etap, struktury, formy, organizatsiia [The re-evacuation of Belarusian refugees of the First World War: the first stage, structures, forms, organisation]," in M.M. Krom, ed., Istochnik, istorik, istoriia [Source, Historian, History] (SPb.: European University, 2002), 396-416.

52. Resolution of the Central Executive Committee of the Union of Communes of the Northern Region, 12 June 1918. Tsentral'nyi gosudarstvennyi arkhiv Sankt Peterburga, f. 75, op. 1, d. 10,1. 6. I thank Valentina Utgof for this reference. 
These administrative changes preceded another enormous round of population displacement. The Russian Civil War obstructed the return of World War refugees to their former homes and also caused civilians to move from place to place in search of safety in order to evade conscription, forced labour, deportation or worse. Between May and November 1918, around 400,000 refugees left Russia for territory that was under German occupation, for example in Kiev, and this scenario was repeated elsewhere, as cities such as Riga and Vilno constantly changed hands during the civil war. Further north, the Baltic region turned into a battleground in which new national armies in Latvia and Lithuania contended with "White" forces, with the Red Army, and with troops under the command of the infamous General von der Goltz. Meanwhile, Poland's occupation of Belorussia and parts of Volynia led contemporaries to observe that the roads in and out of towns such as Minsk were crowded with refugees and "speculators." Conversely, the Soviet invasion prompted an exodus of propertied Poles from towns such as Bialystok. The civil war had particularly pernicious consequences for Jews, some of whom tried to make their way westwards in order to avoid pogroms..$^{53}$

By 1921, diplomatic agreements between the Soviet state and its neighbours facilitated a further round of repatriation, which called for the registration of refugees who were entitled to be furnished with the necessary documents. Around 1.3 million Poles were repatriated from Soviet Russia, for example. ${ }^{54}$ At this stage, external aid agencies made an important contribution to the process of resettlement. British and American Quakers devoted immense efforts towards assisting repatriated refugees. This took place against the backdrop of frequently unhelpful policies adopted by 'bourgeois' states towards "re-evacuees," some of whom they mistrusted on political or ethnic grounds or believed to constitute a health threat. Generally speaking, the new successor states engaged in nation-building projects that marginalised or excluded those who did not belong to the dominant nationality. ${ }^{55}$

One outcome of revolution and civil war was the exodus of between one and one and a half million refugees - not all of them ethnically Russian - to Central and Western Europe, North America, and the Far East. This exodus is well covered in the literature. ${ }^{56}$ The presence in Europe of stateless Russians and Armenians

53. Kulischer, Europe on the Move, 130-1; Henry Abramson, A Prayer for the Government: Ukrainians and Jews in Revolutionary Times, 1917-1920 (Cambridge, Mass: Harvard University Press, 1999).

54. T.M. Bartele and V.A. Shalda, "Latyshskie bezhentsy v Rossii v gody Grazhdanskoi voiny [Latvian refugees in Russia during the Civil War], Otechestvennaia istoriia, 1 (2000), 18-31.

55. Lester M. Jones, Quakers in Action: Recent Humanitarian and Reform Activities of the American Quakers (New York: Macmillan, 1929); see also the essays in Baron and Gatrell, eds, Homelands.

56. The classic pre-1945 study is Sir John Hope Simpson, The Refugee Problem: Report of a Survey (Oxford: Oxford University Press, 1939), 62-116, with a discussion of statistics on pp. 80-83 covering the years 1920-1922. Specialist works include Marc Raeff, Russia Abroad: A Cultural History of the Russian Emigration, 1919-1939 (New York: Oxford University Press, 1990), and Robert H. Johnston, New Mecca, New Babylon: Paris and the Russian Exiles, 
prompted new relief organisations to proffer assistance, whilst the new League of Nations debated the legal status of these refugees. The League's high commissioner for refugees, Fridtjof Nansen, with a tiny office and a modest budget, relief heavily on voluntary relief organisations to provide refugees with material support. Zemgor in particular played a prominent part in this emerging international refugee regime..$^{57}$

Along with other relief organisations Zemgor was closely involved in aiding refugees, particulalry in war-ravaged Armenia, in Constantinople, and in territories that hitherto formed part of the Ottoman Empire. ${ }^{58}$ Humanitarian assistance was again informed by cultural representations of displacement. An American correspondent reported on the plight of 20,000 Armenian refugees in Tbilisi in 1918: these people made for "a droll and pathetic sight." His report was directed at a transatlantic readership. It did not stint on graphic images of distress, degradation and hunger. Thus, in Aleksandropol' and Yerevan he encountered emaciated refugee "children, but I really mean wizened and ancient dwarfs" living among adults who "showed the gentle somnolence of lotus eaters." ${ }^{9}$ In the Caucasus in particular, Anglophone and Francophone humanitarian involvement on behalf of Armenian refugees included a strong Christian dimension, something also evident in the title of the book of stories (The Cross) collected from Armenian survivors of the genocide by the Armenian doctor Aram Sahakian (1884-1968), who worked as resident doctor at the main refugee camp in Port Said.$^{60}$ These relief efforts and cultural representations of disease and degradation, carrying more than a whiff of "orientalism," persisted into the 1920s. ${ }^{61}$

Nonetheless, a purely Western perspective is partial and misleading. Humanitarianism derived from a variety of sources, rested upon various motives and took a variety of forms of expression. To be sure, Russian and Armenian refugees became

1920-1945 (Montreal: McGill University Press, 1988). Among more recent contributions mention may be made of Klaus Schlögel, Der grosse Exodus: die russische Emigration und ihre Zentren 1917 bis 1941 (Munich: C.H. Beck, 1994), and Catherine Gousseff, L'exil russe: la fabrique du réfugié apatride, 1920-1939 (P.: CNRS, 2008).

57. Catherine Gousseff and Olga Pichon-Bobrinskoy, "The invention of a humanitarian policy: Russian refugees and Zemgor, 1921-1930," Cahiers du Monde russe, 46,4 (2005): 667-672; Claudena Skran, Refugees in Inter-War Europe: the Emergence of a Regime (Oxford: Clarendon Press, 1995); Bruno Cabanes, The Great War and the Origins of Humanitarianism, 1918-1924 (Cambridge: Cambridge University Press, 2014).

58. Jennifer Grieve-Laing, "Russian refugee relief aid in inter-war Europe: The case of Constantinople, 1920-1922" (unpublished PhD, University of Aberdeen, 2016).

59. Melville Chater, "The Land of Stalking Death," National Geographic Magazine, 36, 5 (1919): 403-418.

60. M. Salbi, The Cross (Studio City, CA: Manjikian Publications, 2014; first published in Armenian, P., 1921).

61. Leshu Torchin, "Ravished Armenia: Visual Media, Humanitarian Advocacy and the Formation of Witnessing Publics," American Anthropologist, 108, 1 (2006): 214-220; Keith David Watenpaugh, “The League of Nations' Rescue of Armenian Genocide Survivors and the Making of Modern Humanitarianism, 1920-1927," American Historical Review, 115, 5 (2010): 1315-1339. 
a major focus of international humanitarian concern. ${ }^{62}$ Within the successor states, foreign relief workers such as the American Jewish Joint Distribution Committee and the Society of Friends (Quakers) played an important part in assisting refugees irrespective of ethnicity. ${ }^{63}$ But not all humanitarian relief work emanated from outside. Armenian refugees benefited from foreign relief programmes, but Armenian organisations were also active in Constantinople in 1918-1922. ${ }^{64}$ Nor should we overlook the concerted efforts of the new Armenian socialist republic to assist Armenians who had been displaced by war and genocide. ${ }^{65}$ Class-based programmes linked the rehabilitation of refugees to fundamental social and economic transformation, whether of Eastern Europe or the Near East. But this is another story. ${ }^{66}$

\section{Refugee voices}

Throughout the twentieth century refugees confronted all manner of challenges in expressing their opinions. Then, as now, refugees were normally seen rather than heard, except in the very specific circumstances associated with making a claim to asylum. As a result, and as implied in the foregoing discussion of contemporary observations by Thurstan, Pollock and Nikol'skii, much of what appears in the documentary record reflects external perspectives and priorities ${ }^{67}$ Occasionally the fog lifts, allowing the reader to glimpse something of refugees' perspectives. For instance, an editorial in an obscure Russian publication issued by a group of refugees lamented that "we long to become people once again. We are living people

62. Michael N. Barnett, Empire of Humanity: A History of Humanitarianism (Ithaca: Cornell University Press, 2011).

63. Joseph Van Gelder, "Activities of the Refugee Department, American JDC in Europe during the Years 1921, 1922, 1923" (1924), copy in the JDC Archives, New York; Ruth Fry, A Quaker Adventure: The Story of Nine Years' Relief and Reconstruction (London, Nisbet, 1926); Rufus Jones, Quakers in Action: Recent Humanitarian and Reform Activities of the American Quakers (New York, Macmillan, 1929).

64. Lerna Ekmekçioğlu, Recovering Armenia: The Limits of Belonging in Post-Genocide Turkey (Stanford: Stanford University Press, 2016), 22-27.

65. The most important humanitarian relief organisation was Near East Relief. See James L. Barton, The Story of Near East Relief 1915-1930: An Interpretation (New York: Macmillan, 1930); Peter Gatrell and Joanne Laycock, “Armenia: the 'Nationalization', Internationalization and Representation of the Refugee Crisis," in Baron and Gatrell, eds, Homelands, 179-200; Keith David Watenpaugh, Bread from Stones: The Middle East and the Making of Modern Humanitarianism (Berkeley: University of California Press, 2015).

66. Nansen evinced a keen interest in the attempts of Soviet Armenia to promote sustained economic development. Fridtjof Nansen, Armenia and the Near East (New York: Duffield, 1928). See also Davide Rodogno, "'Non-State Actors' Humanitarian Operations in the Aftermath of the First World War: The Case of the Near East Relief," in Fabian Klose, ed., The Emergence of Humanitarian Intervention: Ideas and Practice from the Nineteenth Century to the Present (Cambridge: Cambridge University Press, 2015), 185-207.

67. Nando Sigona, "Memories, Narratives and Representations of Forced Migration," in Elena Fiddian-Qasmiyeh et al, eds, The Oxford Handbook of Refugee and Forced Migration Studies, 369-382. 
[with] the misfortune to have been displaced, but we are human beings all the same." ${ }_{68}$ But this kind of testimony is very rare.

Perhaps most remarkable in terms of its content were the words of a female eye-witness - unfortunately, nothing of is known of her other than her name and gender. In a contribution to another short-lived journal, Sputnik bezhentsa [The Refugee's Guide] she wrote:

Not so long ago, these people lived a full and independent working life. They had the right to be just like us, that is, indolent, rude and ungrateful. Now they have lost this prerogative; their poverty and helplessness oblige them to be meek and grateful, to smile at people they don't like, to answer each and every question without the right to ask questions of their own, to submit to the authority of people they don't respect and have no wish to know, to accept disadvantageous terms from those who wish to take advantage of their poverty and misfortunes ... ${ }^{69}$

Her observations have surely never been bettered as an eloquent expression of empathy, yet its poignancy and directness of tone only reinforces the point that most testimony is mediated by non-refugees.

It is worth drawing attention to the far-sighted recognition by the Tatiana Committee of the need to create an archive of its activities, its guiding principles, and the impact of its actions on refugees. Its attempts, perhaps inevitably, were rather triumphalist in tone, but in soliciting letters from refugees the committee demonstrated its willingness to listen to the voices of refugees. The committee issued a detailed questionnaire at the end of 1916, which was accompanied by the remark that refugees should be "free to express themselves." No other relief agency took such a bold and imaginative step, and aid agencies have struggled ever since to do something similar. ${ }^{70}$ Some of the results were remarkable. Iakov Vol'rat, an elderly refugee, identified as a "refugee-volost scribe from Kurland province," writing from Odessa in December 1916, vividly described the pain and torment he and his family (a wife and five daughters) suffered as a result of being forced to flee from his village in a great hurry before making his way to European Russia where he eventually found work with the Latvian refugee relief committee. The most striking aspect of his testimony was his comment that "my life as a forced migrant in a foreign land (na chuzhbine) has been interesting from the point of view of observing human life." Although many Latvians were anxious lest their Russian hosts mistake them for Germans, in fact Vol'rat found nothing but sympathy and support. Had he not been a refugee, he concluded, he would have been deprived of

68. Bezhenets, 18 October 1915.

69. E. Vystavkina, "Ikh dushi [Their souls]," Sputnik bezhentsa, September-October 1915.

70. Izvestiia Komiteta ee Imperatorskogo Vysochestva Velikoi Kniazhny Tatiany Nikolaevny dlia okazaniia pomoshchi postradavshim ot voennykh deistvii, no. 15 (1916). Some short extracts from refugees' correspondence appeared in Vera Slavenson, "Bezhenskoe: po povodu pisem bezhentsev [Refugeeness: concerning refugees' letters]," Vestnik Evropy, 51, no.7 (1916): 292-301. See also Simon Harris, "Listening to the Displaced: Analysis, Accountability and Advocacy in Action," Forced Migration Review, 8 (2000): 20-21. 
the opportunity late in life to get to know "places, people and customs" in Russia. There was, his testimony suggested, much more to displacement than trauma. ${ }^{71}$

The Tatiana Committee was also instrumental in organising an exhibition of refugees' handicrafts. Construed as an initiative "of general state significance," the aim was largely to demonstrate that refugees were hard-working and not dependent solely on state aid. But it also served to underscore the fact that refugees had introduced "new forms of handicraft production," as peasant refugees from Galicia had begun to do in Siberia and other "remote corners." Here, significantly, was the idea of the refugees as Kulturträger. More broadly, the exhibition was conceived as an opportunity to tell the story of refugees' flight (including, not surprisingly, the brutality of the enemy) and resettlement and to create a legacy for the future - "a history of the movements of refugees." To this end, the organisers invited people to submit "photographs, sketches, maps (kartogrammy), diagrams, reports, and so on." 72 Although the initiative ended with the February Revolution, it draws attention to an imaginative strand of thinking on the part of Russia's professional intelligentsia: personal testimony could include material objects as well.

The voice of the individual emerges only intermittently in the immediate aftermath of the First World War. In May 1919 a group of Polish teachers in Riazan' complained of their desperate material plight, but added that their wish to return to Poland was prompted by grander ambitions: "we have a natural wish to go back to our native country, where a new and brighter future awaits us in free Poland [...] we are anxious to re-establish contact with our families who remained behind there, and we have a passionate desire to serve our homeland during the difficult time of its foundation." ${ }^{\prime 3}$ In a diary entry, Alfreds Goba, a young Latvian refugee who moved back to "new Latvia" from his temporary domicile in Baku, wrote: "Now I am working. I am working towards building a new Latvia." Three months later Goba welcomed Germany's readiness to engage in peace negotiations, but hoped that the future would bring freedom from German and Russian tutelage alike:

I don't know if something bad happened in Latvian affairs or if for some other reason Latvia, like me, has to be between Scylla and Charybdis. One master isn't yet gone and already another is near to rule and suckle [...] Latvia, Latvia you

71. "Begstvo ot germantsev i skitaniia [Flight from Germans and wandering]," Izvestiia Komiteta, no. 19 (15 April 1917): 17-22. See also Gatrell, The Making of the Modern Refugee; and Malkii, Purity and Exile.

72. Izvestiia Komiteta, no. 21 (1916): 13. For analogous exhibitions in Austria-Hungary, see Julie Thorpe, "Displacing Empire: Refugee Welfare, National Activism and State Legitimacy in Austria-Hungary in the First World War," in Panikos Panayi and Pippa Virdee, eds, Refugees and the End of Empire: Imperial Collapse and Forced Migration in the Twentieth Century (Basingstoke: Palgrave, 2011), 102-126 (112-113). In the late nineteenth century the Red Cross had organised exhibitions to advertise its humanitarian relief efforts. See Bertrand Taithe, "Humanitarian History?" in Roger Mac Ginty and Jenny H. Peterson, eds, The Routledge Companion to Humanitarian Action (London, Routledge, 2015), 62-73.

73. Petition dated 1 May 1919, GARF (Gosudarstvennyi arkhiv Rossiiskoi Federatsii), f. 3333, op. 1a, d. 102, 1. 86, quoted in Gatrell, A Whole Empire Walking, 186. 
have lived a hard and slavish orphan life, and still you are like a child. Will you survive? Will you be able to stand on your own two feet?

Goba saw a close fit between the need to establish his family on more secure material foundations and Latvia's search for national liberation. ${ }^{74}$ This is a reminder that personal testimony was connected to broader narratives and ambitions.

The attempt to ascertain refugees' perspectives on their experiences of exile emerged in a small yet politically significant project undertaken by Baroness Mariia Vrangel', the mother of the famous White Russian general, who issued questionnaires to around 400 refugees who fled Russia after the Bolshevik Revolution. A recent analysis of her findings concludes that Russian émigrés drew a clear distinction between their identity as "authentic" Russians and other exiles of non-Russian ethnicity, particularly Jews, as well as anyone who had emigrated before 1914 for what were deemed to be "economic" reasons. These various groups were excluded from "Russia abroad." Political differences also surfaced in the diaspora: one of Vrangel's informants studiously castigated those who had not fought for the White armies as mere "refugees" who did not deserve the epithet of "exiles." Displacement, in other words, emphasized exclusion and exclusiveness - or, put another way, some voices counted more than others. ${ }^{75}$

\section{Conclusions}

This article began by considering the production of silence about refugeedom and indicated how it contributed to the impoverishment of the historiography of war and revolution. But the prospects for an approach unfettered by previous perspectives and shibboleths were not damaged irretrievably. After a protracted lack of attention, the impact of war and revolution on refugees in Russia has become an active topic of research. The literature has rediscovered what contemporaries understood, namely that mass population displacement posed fundamental questions about state legitimacy. The tsarist regime neither prevented enemy incursions that propelled people from their homes in vast numbers - indeed, it directly contributed to forced migration - nor did it have the capacity to address the plight of refugees. Public organisations, notably Zemgor, and newly-formed national committees rushed to fill that gap by claiming to act more effectively on behalf of refugees as "victims of war." The tsarist state was nevertheless heavily involved

74. I am grateful to Aldis Purs for permitting me to quote from his translation of the Goba diary (the emphasis in the quotation is mine).

75. A respondent living in Cairo objected that the local Club of United Russians "is only Russian by name - three quarters of its members are Yids." See Laurie Manchester, "How Statelessness Can Force Refugees To Redefine Their Ethnicity: What Can Be Learned From Russian Émigrés Dispersed To Six continents in the Inter-War Period?," Immigrants and Minorities, 34, 1 (2016): 70-91, quotation on p. 76. Manchester's article draws upon the papers of Vrangel' held by the Hoover Institution Library and Archives. 
indirectly in refugee relief, since it held most of the purse-strings. It devolved day-to-day responsibility on to other agencies, including the semi-official Tatiana Committee, which forged a working relationship with the public organisations and with the national committees.

The Tatiana Committee explicitly relied upon imperial patronage, but its elite association did not turn it into a backward-looking institution. Many of the actions of the Tatiana Committee have a modern ring. In addition to its attention to detail in establishing feeding points and health care, the committee attached great importance to counting heads in order to establish the potential demand for basic necessities at a time of constrained resources. Another priority was to enable refugees to make contact with one another. The committee also committed itself, albeit belatedly, to engaging with refugees on the basis of mutual respect. It demonstrated a willingness to listen to refugees and to emphasising that refugees were capable and hard-working rather than apathetic and hopeless individuals. Modern humanitarian relief work relies heavily on endorsement by celebrities from the entertainment industry and from sport. Tsarist Russia had a humanitarian figurehead in the shape of Tatiana, but tsarism was a tainted brand, and revolutionary rhetoric soon removed the more enterprising activities of the Tatiana committee from public view. ${ }^{76}$ This belonged to a broader and concerted process that minimised the political significance of the refugee crisis and the actions of those who sought to alleviate it, and contributed to the marginalisation of refugees' experiences of "suffering" and "deliverance" after 1917.

The new historiography of refugeedom has also begun to address the relationship between war, revolution, state formation, and population displacement. It directs attention to the ways in which the mobilisation of refugees gave the patriotic intelligentsia among non-Russian national committees unprecedented and considerable experience of practical administration, enabling them to develop a kind of embryonic government bureaucracy. This perspective reverses the link between the formation of nation-states and the "refugee-generating process." In other words, refugees were the product of the formation of new nation-states after 1918, but displacement was also the precursor to state formation. ${ }^{77}$

As we have seen, the humanitarian response to the wartime refugee crisis in Russia was heavily politicised. In this respect, tsarist Russia conformed to modern practices of humanitarianism, insofar as non-governmental organisations and inter-governmental organisations such as the League of Nations and (since 1951) the Office of the UN High Commissioner for Refugees cannot avoid engaging with

76. On the tsarist "brand," see the fundamental work by Boris Kolonitskii, "Tragicheskaia erotica": obrazy imperatorskoi sem'i v gody Pervoi mirovoi voiny [Tragic erotica: representations of the imperial family during the First World War](M.: Novoe literaturnoe obozrenie, 2010).

77. Aristide Zolberg, "The Formation of New States as a Refugee-Generating Process," Annals of the American Academy of Political and Social Science, 467 (1983), 282-296. 
politics, even as they affirm their apolitical stance. ${ }^{78}$ Political considerations also inflected humanitarian relief efforts after 1917. Soviet Russia's isolation contributed to a sense that the chief humanitarian impulse lay outside Soviet borders, or had to be imported at times of emergency such as through the special arrangements that enabled the American Relief Administration to engage in relief work during the famine of 1921-1922. This external relief was highly politicised. ${ }^{79}$ However, humanitarianism was not just about national and international intervention. On the contrary, local efforts to engage with displaced people should not be overlooked. They retained their importance in the aftermath of the revolution, even though revolution and state formation created very different conditions making life much more uncertain for refugees.

There is a pressing need to confront entrenched historiographical positions regarding Russia's experience of war and revolution. The dominant narratives of revolution found little room for social activity and experiences that could not easily be accommodated within the framework of conventional political organisations or linked to the revolutionary teleology that legitimised the Bolshevik seizure of power. Refugees were overlooked in these narratives; they did not "fit in," and their voices went unheard. The "new social history" of revolution concentrated upon organised social forces, whose actions impinged directly on the existing forms of state power and whose spokesmen left behind compelling accounts of political struggle. The conceptualisation of displacement offered in this article, together with the various manifestations of refugee relief efforts, invites us to extend our focus without losing sight of broader issues of social and political transformation. Refugees may have lived on the margins, but "the apparently marginal, when set in relation to other phenomena, can lay bare the unacknowledged workings of larger systems of power." 80

\section{University of Manchester}

peter.gatrell@manchester.ac.uk

78. Taithe, "Humanitarian History?"; Eleanor Davey and Kim Scriven, "Humanitarian Aid in the Archives: Introduction,” Disasters, 39, Special issue S2 (2015), S113-128.

79. On the ARA, see Bertrand Patenaude, The Big Show in Bololand: The American Relief Expedition to Soviet Russia in the Famine of 1921 (Stanford: Stanford University Press, 2002).

80. S.A. Smith, "Writing the History of the Russian Revolution after the Fall of Communism," Europe-Asia Studies, 46, 4 (1994): 563-578 (quotation on p. 569). 